\title{
Os desafios do protagonismo leigo
}

\author{
The challenges of the laity
}

João Décio Passos

\section{Resumo}

A presente reflexão pretende aproximar da problemática complexa da relação clero e leigo na Igreja. Essa distinção construída na longa temporalidade resultou, em muitos casos, numa dicotomia entre as lideranças eclesiais e o conjunto do povo cristão. Seguindo esquemas antigos de poder que dualiza de modo natural e divino os detentores de sacralidade e de superioridade em relação aos não sagrados e destituídos de poder, o clericalismo foi sendo construído e ainda persiste nas práticas eclesiais atuais. A reflexão levanta essa problemática, expõe o processo de construção da dicotomia, apresente uma tipologia das leituras equivocadas sobre a questão e conclui com indicações de modos de superação. Ainda que a distinção clero e leigo estruture a organização eclesial, ela pode e deve fundar no serviço e não no poder. A reforma inadiável da Igreja convocada pelo Papa Francisco exigirá renovação tanto das mentalidades quanto das práticas pastorais e canônicas que regem a práxis ministerial na mesma Igreja. A vida eclesial organizada em pequenas comunidades possibilita formas de vivência ministerial que superam as dicotomias e legitimam unicamente o serviço.

Palavras-chave: Clero; Igreja; leigo; ministérios; serviço.

\section{Abstract}

The present reflection pretends to approach on the complex problematic relationship between the clergy and the laity in the church. This distinction built on long temporality resulted, in many cases, a dichotomy between Church 
leaders and the entire Christian people. Following ancient model of power that dichotomies natural and divine way, the holders of sacredness and superiority to not sacred and powerless, clericalism was being built and still persists in the current ecclesial practices. The present reflection raises the problem and exposes the process of building the dichotomy and brings out a typology of equivocal readings on the issue and concludes with modes of indications of overcoming it. . Still clergy and laity distinct on structures in the ecclesial organization, it can and must be based on service and not in power. The urgent reform of the Church convened by Pope Francisco will require renovation both in attitudes as well as in the pastoral and canonical practices in governing the ministerial practice in the Church. The ecclesial life organized in small communities is the possibility of new forms of ministerial experience that surpass the dichotomies and only legitimates service.

Keywords: Clergy; Church; Laity; ministries; service.

\section{Introdução}

O presente texto se insere no contexto da Semana Teológica da Pontifícia Universidade Católica do Rio de Janeiro e Instituto Franciscano de Petrópolis, realizada em Outubro de 2014. A Semana focou a temática do leigo na Igreja, em uma feliz convergência com o processo de estudo do Documento 107 da CNBB pelas dioceses do Brasil. A reflexão sobre o leigo na Igreja, ora encaminhada, situa-se, portanto, nesse processo e reflete em muitos pontos a experiência do autor na produção do mesmo Documento na equipe que o elaborou no âmbito da CNBB. A questão do leigo na Igreja tem solicitado revisitações constantes por parte da teologia desde antes do Vaticano II, certamente não somente por se tratar de um item central da eclesiologia, mas também por constituir uma questão disputada, tanto do ponto de vista prático quanto teórico. $\mathrm{Na}$ verdade, o marco conciliar, divide a teologia do laicato em duas temporalidades e concepções distintas, embora os resíduos eclesiásticos pré-conciliares e uma certa teologia por demais institucional, centrada no poder, contribuiu com a permanência daquela divisão dicotômica entre clero e leigo. A argumentação tem como tese central que essa dicotomia historicamente construída nega os fundamentos mais radicais da vida eclesial. Nas origens não era assim. Contudo, a distinção clero-leigo pode ser vivenciada como serviço, mesmo que estruturalmente permaneça como modo de organização 
da Igreja. Não há como ignorar, entretanto, o dado real da estruturação dual da Igreja entre cleros e leigos, com sua longa temporalidade e sua pesada carga de justificação teológica e embasamento canônico. Mesmo tendo o Vaticano II oferecido uma nova eclesiologia diretamente ligada a uma nova teologia do laicato, a dualidade clero-leigo resistiu às mudanças, amparada pela preservação quase intacta da estrutura hierárquica anterior ao evento conciliar.

O foco central da reflexão é sobre a dicotomia clero-leigo, sendo o clericalismo a expressão visível de uma compreensão do ministério ordenado como superior ao povo, como poder sagrado de onde provém juridicamente a organização eclesial e, por conseguinte, onde se insere o leigo como figura subalterna. O clericalismo é a negação perversa do ministério-serviço em nome de uma compreensão e prática centradas no poder de cunho religioso-político-jurídico. Nesse contexto, ser um autêntico sujeito eclesial (cf. Documento de Aparecida, 497) constitui um desafio para os leigos; em muitos casos um enfrentamento com a tendência clericalista que dispensa o leigo de seu protagonismo. A Igreja em saída, toda missionária e entregue ao serviço do outro, especialmente dos mais pobres, terá que superar o clericalismo, sob pena de somente fazer discursos vazios sobre o laicato e de encenar mudanças, enquanto permanece com sua "hierarcologia" intacta.

\section{Colocação do problema: o clericalismo}

Aqui estamos para falar novamente de leigos na Igreja. É verdade que a teologia - estamos em uma academia dessa área de conhecimento - existe para falar de novo, para ler os sinais dos tempos e em cada época e lugar falar da novidade da Palavra que, ao mesmo tempo, ilumina os contextos e é por ele interrogada. Isso bastaria para justificar a presença dessa temática tão refletida, sobretudo depois do Concilio Vaticano II. Mas, não é somente por essa razão metodológica; é também por uma razão mais intrigante: o leigo permanece como um problema eclesiológico e, em muitos casos, como um problema eclesial; permanece como um sujeito - se assim pode ser denominado - de segunda categoria, com menor direito que o clero, em condição inferior na Igreja, mais na condição de paciente do que de agente ativo na vida da Igreja. Isso é assustador, se pensarmos não somente naquilo que decidiu e orientou o Vaticano II sobre a temática, mas, no que significou a ação e a organização do laicato, já antes e, sobretudo, depois do Concilio, de modo particular na América Latina. ${ }^{1}$

${ }^{1}$ Cf. PASSOS, J. D. Concilio Vaticano II: reflexões sobre um carisma em curso. São Paulo: Paulus, 2014, pp. 109-163. 
No epicentro do Concilio o leigo adquire, de fato, um novo status eclesial: como Igreja e não como pertencente à Igreja (Pio XII), como membro do corpo de Cristo e povo de Deus (Lumen Gentium), como enviado à ação dentro e fora da Igreja por direito e dever (Gaudium et Spes e Apostolicam Actuositatem). E a ação organizada do laicato deu passos significativos nesses anos de pós-concílio. A Igreja por meio dos leigos marcou presença ativa na sociedade brasileira no período de reconstrução democrática. Sem a Igreja, certamente, a nossa história de redemocratização não teria sido a mesma. As pastorais sociais avançaram enormemente. Pensemos na Pastoral da Criança, organizada, coordenada e executada por leigas, na Comissão Pastoral da Terra, na participação dos leigos na animação das CEBs etc. Há que ressaltar também, do ponto de vista da organização do segmento leigo, as diversas formas de ministérios espontâneos e instituídos que atuaram dentro e fora da Igreja, possibilitando vivências eclesiais nas pequenas comunidades nos lugares mais distantes do território nacional, onde a presença efetiva do presbítero é esporádica. Também a organização do laicato no Conselho Nacional de Leigos, hoje CNLB, construiu uma longa história de presença ativa dos leigos na sociedade brasileira, dando continuidade à Ação Católica. ${ }^{2}$ A recepção do Concilio na América Latina ocorreu com a participação sempre mais ativa dos leigos, na medida em que as Igrejas locais se inseriam na sociedade e se estruturavam internamente em novas formas de organização pastoral e ministerial.

Contudo, essa fase eclesial demonstra cansaço e desgaste. No lugar da participação ativa do leigo, em comunhão estreita com os presbíteros, vai tomando forma a dualização entre clero e leigo, como segmentos eclesiais distintos e opostos. Podemos observar com frequência medo e insegurança por parte de membros da hierarquia em relação ao laicato. Muitas posturas e afirmações são flagrantes de clericalismo tridentino, superado pela doutrina do Vaticano II. Para muitos a organização do laicato não está dentro dos parâmetros do Direito Canônico. As organizações laicais devem justificar-se pela lei para serem legítimas dentro da Igreja; é da lei que vem a segurança de que os leigos podem se organizar de modo autônomo dentro da Igreja. Em algumas dioceses a organização deve ficar subordinada ao clero para que possa ser legitimamente eclesial. No processo de elaboração do Documento $107^{3}$ não faltaram sugestões que

${ }^{2}$ Cf. AGUIAR, G. A organização e a articulação do laicato na forma de Conselho de leigos. In: PASSOS, J. D. (Org.) Sujeitos no mundo e na Igreja: reflexões sobre o laicato a partir do concilio Vaticano II. São Paulo: Paulus: 2014, pp. 259-283.

${ }^{3}$ CNBB. Cristãos leigos na Igreja e na sociedade: sal da terra e luz do mundo (cf. Mt 5,13-14). Brasília: Edições CNBB, 2014. 
dispensavam o estudo do assunto como desnecessário, sob a alegação de que já existiam muitos documentos. Outras sugestões inquiriam os conceitos de sujeito e de autonomia como perigosos para a Igreja, ignorando seus conteúdos essencialmente evangélicos. A concepção de que o leigo exerce sua missão como subordinação à hierarquia, superada pela teologia conciliar, resiste e cresce dentro da Igreja em nossos dias e, com muita frequência, busca seu fundamento numa eclesiologia de comunhão que não encontra sinônimos na eclesiologia do Vaticano II e nem na Exortação Christifidelis Laici. Onde houver subordinação não haverá verdadeira comunhão, mas sim domínio que gera pessoas passivas e uniformização que nega a liberdade.

Será necessário fundamentar novamente a natureza e a missão do leigo na Igreja? Paira um esquecimento assombroso sobre as decisões e as recepções do Vaticano II na questão do laicato em muitos ambientes eclesiais. Como dantes do Vaticano II, retomou-se a figura do diretor espiritual ou do assessor eclesiástico encarregados de dirigir as pastorais e outras formas de ação e de associação laicais. Não se trata de julgar pessoas ou práticas, mas de perceber o que revela o imaginário com essas figuras: os trabalhos leigos são reconhecidos se houver na frente um membro do clero. Essa clericalização se expressa nos últimos tempos em vários modos e esferas da organização pastoral da Igreja. Muitas dioceses e paróquias abandonaram as Assembleias de pastoral e adotaram formas decisórias centralizadas que dispensam a participação dos leigos. Várias das chamadas novas comunidades trilham um percurso cujo ponto almejado é se tornarem de direito pontifício à maneira das congregações religiosas, associações religiosas laicas usam hábito, muitos movimentos leigos defendem posição de isolamento do mundo como estratégia de sobrevivência eclesial e enfrentam a sociedade atual como franca inimiga etc. A clericalização se torna não somente uma prática sempre mais visível, como também um caminho de legitimação para as atividades organizadas do laicato. Não acreditamos no anarquismo eclesial e nem na ausência de ministérios destinados a dirigirem a Igreja em nome de uma vivência carismática pura. A liderança ex officio existe em qualquer instituição e é necessária para a sobrevivência e ação da mesma. Em nosso caso, sabemos que os ministérios eclesiais têm uma raiz teológica: originam-se dos dons que recebemos do Espirito para servir a Igreja e o mundo (cf. 1Cor 12-14). É desse carisma original que têm origem os ministros instituídos nos vários modelos construídos no decorrer da história. No cristianismo não tem lugar nem o anarquismo e nem o poder absoluto, mas acolhida aos dons do Espirito que gera a organização 
dos ministérios para a edificação da Igreja. O apóstolo Paulo ensina essa regra à comunidade de Corinto, quando afirma, ao mesmo tempo, a "democracia" dos dons e a hierarquização dos serviços (cf. 1 Cor 12, 27-31).

No entanto, o quadro eclesial revela um grande paradoxo. O leigo, imensa maioria da Igreja, como relembra o Papa Francisco (EG, 102), é quem sustenta as pastorais, para não tocar na questão da sustentação financeira. Esse é o dado prático que advém do Vaticano II e que reestruturou toda a ação e organização da Igreja no seu interno e na sociedade, sobretudo no Brasil. Sem a ação do laicato as pastorais se extinguiriam. Nesse sentido, o clericalismo se revela um poder frágil, não fosse antes um pecado contra a comunhão do corpo eclesial, feito de unidade na diversidade. Sua fragilidade política significa a impossibilidade história e eclesial de se pensar um comando centralizado e oligárquico das pastorais, ainda que esse possa ser exercido do ponto de vista canônico. A imagem de uma Igreja gerida por clérigos existe somente como "certa imagem" residual e como poder instituído canonicamente. Na prática, nem as comunidades eclesiais nem a sociedade concedem ao clérigo esse poder que no passado se impunha com naturalidade, seja pelo modelo de Igreja essencialmente hierárquico, seja por uma sociedade que via no clero uma fonte quase exclusiva de informações religiosas e, até mesmo, de informações culturais gerais. $\mathrm{O}$ clero está hoje restrito somente a uma função que lhe é própria, a de coordenar e animar a organização das comunidades eclesiais. O que for além disso, pode até encontrar admiradores, porém paira em uma esfera de poder ilusório e de uma casta que vive para si mesma, sem credenciais políticas e éticas perante o povo de Deus. Vale lembrar, ainda, que o clericalismo que, por certo nasce do clero, não se restringe a esfera do mesmo; ele se torna um modo de pensar e de agir que circula de alto a baixo nas funções e serviços eclesiais. A convicção de que se está investido de um poder sagrado e superior do qual decorrem poderes subalternos em uma escala hierárquica é que constitui a essência do clericalismo, tanto os eclesiais quanto os políticos. Nesse sentido, o clericalismo é antes de tudo um exercício centralizador e autoritário do poder que divide estruturalmente uma comunidade em superiores e subordinados, em conhecedores e ignorantes, em sujeitos e pacientes. No caso católico, entre cleros e leigos ou entre leigos líderes investidos de algum poder e leigos passivos.

Não é preciso lembrar que essa estruturação sócio-política é estranha ao cristianismo, ainda que tenha dele se apropriado no decorrer da história. A comunidade cristã inaugura um novo modo de convivência social que rompe tanto com a estratificação do Império Romano quanto com os individualismos 
das escolas filosóficas. Embora as distinções etimológicas dos termos clero $($ kleros $=$ sorteado $)$ e leigo $(\text { laós }=\text { povo })^{4}$ apontem, de fato, para um outro tipo de concepção e organização eclesial não dicontômica, elas não solucionam o que foi historicamente construído como mentalidade e como pratica que se tornaram tradicionais e, até mesmo, em muitos casos, dogmáticas.

\section{A construção da dicotomia}

$\mathrm{O}$ cristianismo nasceu rompendo com qualquer distinção de posição de poder dentre os seus membros e fora do esquema sacerdotal do judaísmo. Não cabe em seu status nascendi qualquer distinção entre clero e leigo, embora haja, em termos sociológicos, a distinção entre o especialista religioso e o usuário comum. O Novo Testamento fala em várias figuras de especialistas na comunidade cristã primitiva: apóstolo, profetas, doutor (cf. 1 Cor 12,27), evangelista, pastor (cf. Ef 4,11), presbítero (1Tm 5,17-25; Tt 1,5-9), epíscopo (1Tm 3,1-7), diácono e diaconisa (cf. 1Tm 3,1; Rm 16,1). No entanto, trata-se de figuras investidas de funções especificas e não de poder sagrado, aliás sequer deveriam ser entendidas como poder, conforme exorta São Paulo na Carta aos coríntios (cf. 1Cor 12, 12-31). Eram figuras que exerciam poderes de tipo carismático $^{5}$, na medida em que estavam ligadas diretamente ao Senhor ou a segunda geração de discípulos. Esse dado não pode ser esquecido, ainda que tenha perdido seu caráter normativo para a estruturação concreta dos serviços instituídos dentro da Igreja. É verdade que essa fonte tem sido referência para as teologias da Igreja e dos ministérios construídos já antes do Vaticano II. No entanto, não inspira e muito menos sustenta os modos de organização da Igreja, desde os tempos antigos, sobretudo a partir do momento em que a Igreja assimilou os modos de organização do Império Romano, essencialmente hierárquicos. $\mathrm{Na}$ verdade, a teologia do sacerdócio já havia sido assimilada bem antes no próprio Novo Testamento, segundo as regras da tipologia, porém concedendo somente a Jesus esse título sagrado, como deixa claro a Epistola aos Hebreus (cf. Hb 7-10). Também Irineu, Inácio de Antioquia e Clemente Romano recorreram ao modelo hierárquico sacerdotal judaico para explicar como deveria ser a organização da Igreja no segundo século. O imaginário sacerdotal foi retomado pelos cristãos no momento na sua fase de institucionalização, já distante no tempo e no espaço

\footnotetext{
${ }^{4}$ A palavra kleros aparece no NT para designar lançamento de sorte como em Mt 27,35 e participação individual como At 1,17 assim como para designar a herança da salvação de todo o povo de Deus como em Cl 1,12. Cf. RUSCONI, C. Dicionário de grego do Novo Testamento. São Paulo: Paulus, 2003.

${ }^{5}$ Cf. WEBER, M. Economía y sociedade. Mexico: Fondo de Cultura Económica, 1997, pp. 193-1976.
} 
do judaísmo sacerdotal, finalizado com a destruição do templo no ano 70 pelos romanos. De fato, a organização da Sinagoga foi o modelo imediato que muitas comunidades cristãs adotaram para a sua organização interna, a partir do momento em que se separam do judaísmo.

Contudo, o processo de rotinização ${ }^{6}$ inerente aos grupos religiosos necessita de formas de organização que garantam a sobrevivência do próprio carisma, sob pena de que esse desapareça ou disperse de tal modo no tempo e no espaço que perca a unidade original do grupo. As chamadas Epístolas Pastorais ( $1^{\mathrm{a}}$ e $2^{\mathrm{a}}$ Timóteo e Tito) são testemunhas eloquentes dos primeiros passos de institucionalização das funções de coordenação da comunidade cristã, ainda no primeiro século. O fato é que, gradativamente, a busca de modelos de organização comunitária se impôs às comunidades cristãs, o que exigiu delas recorrer a modelos já existentes, ou a imagens já construídas que fornecessem ao mesmo tempo os modos concretos de organização e um fundamento legítimo, do ponto de vista teológico. O imaginário sacerdotal foi, por certo, o modelo que, na economia de esforços, se apresentou como mais conatural à comunidade cristã, desprendida do judaísmo oficial, porém preservadora dos textos vétero-testamentários. A imagem da hierarquia sacerdotal estava disponível canonicamente, mesmo que na prática o próprio judaísmo da diáspora a tivesse abandonado no seu sistema de organização sinagogal.

Nos séculos seguintes, com a inserção no Império Romano, a sacerdotalização dos ministérios ${ }^{7}$ adquire maior visibilidade no contexto de uma religião que se massifica, fazendo emergir com maior distinção e diferenciado status político os especialistas e o simples fiel. Clero e leigo já não designam tão somente duas condições religiosas distintas, mas também duas condições político-jurídicas e sócio-culturais que dividia a Igreja entre os especialistas nas coisas sagradas e nos serviços religiosos e os não especialistas, os leigos. No contexto do Império os que ocupam a função sacerdotal serão compreendidos como os pertencentes à ordo, que na Roma imperial designava uma classe social delimitada que se distinguia da plebs (o povo em geral). Essa denominação e essa estruturação social será transposta para a organização da Igreja. Tertuliano é o primeiro a expressar essa distinção eclesial entre ordo (ministros ordenados) e plebs (os fiéis de um modo geral). ${ }^{8}$ Os desdo-

\footnotetext{
${ }^{6}$ Cf. Ibid., p. 197 ss.

${ }^{7}$ Cf. PARRA, A. Os ministérios na Igreja dos pobres. Petrópolis: Vozes, 1991, pp. 139-152.

${ }^{8}$ Cf. TABORDA, F. A Igreja e seus ministérios; uma teologia do ministério ordenado. São Paulo: Paulus, 2012, pp. 22-23.
} 
bramentos históricos são conhecidos. A distinção prossegue sem variações no decorrer da longa idade média, quando, o contexto cultural afirma, ainda mais, a distinção entre os ministros sagrados e letrados em legítima superioridade ao povo, em geral, sem cultura letrada. Vai sendo institucionalizada uma práxis ministerial cada vez mais individualizada (mais centrada no individuo que recebe a ordenação) e absolutizada (como algo por si mesmo efetivo que dispensa o vínculo eclesial). ${ }^{9}$ Devemos concluir que a construção do imaginário dicotômico entre clero e leigo deve ser buscada na longuíssima temporalidade da história do cristianismo, o que se verifica nas praticas eclesiais bem como nas fundamentações eclesiológicas. Tendo em vista essa longa tradição e práxis, seria ingenuidade postular uma Igreja sem clérigos e leigos, numa espécie de poder carismaticamente organizado, ou de um anarquismo eclesial. O próprio modelo paulino, descreve uma Igreja organizada a partir dos carismas, porém gravitando em torno dos Apóstolos. A geração seguinte, sem os Apóstolos, já buscou formas novas e seguras de transmissão do carisma. Esse recurso constitui um momento inerente ao poder carismático, como bem explica Max Weber na sua sociologia do poder. ${ }^{10}$ Contudo, as falsas leituras dessa distinção real devem ser desveladas para que tenhamos consciência do problema e possamos, antes de tudo, vivenciar a eclesialidade com suas construções históricas sempre fundadas no carisma cristão. A fé que fundamenta a Igreja e suas funções fornece norma suficiente para que a dicotomia possa converter-se em parceria, a divisão em comunhão, o poder em serviço. Fora da regra fundamental do serviço decorrente da lei do amor, nenhuma função ou posição se legitima dentro da comunidade cristã.

\section{Algumas leituras equivocadas}

Parece ser precisamente a tensão entre o carisma cristão em status nascendi e as edificações institucionais que possibilita a busca de diferentes leituras da organização eclesial atual, donde podemos observar: a) aquelas que acomodam as duas dimensões em um único olhar ou vinculam as duas fases históricas, a carismática e a institucional, numa continuidade simples (as organizações institucionais como desdobramento natural do carisma fundante) ou até mesmo numa relação direta de causa e efeito (as estruturas históricas nascendo direta-

\footnotetext{
${ }^{9}$ Cf. Ibid., pp. 112-119.

${ }^{10}$ Cf. WEBER, M. Economia y sociedade, p. 857.
} 
mente das origens); b) aquelas que desvinculam de tal modo as duas fases que só resta como forma legitima e viável de organização eclesial a experiência primordial de poder carismático, ou então, a hierárquico-sacerdotal. Ambas as direções ignoram o processo histórico real de construção do cristianismo e fixam-se em um modelo único incapaz de dialogar e de confrontar-se com os novos significados de ontem e de hoje, em nome de uma experiência fundante dada na história e em diálogo com ela. Essas leituras podem ser tipificadas como seguem. Por se tratar de tipificação pretendem ser nada mais que um mapeamento que ajude a enxergar a realidade sem esgotar sua complexidade.

\section{a) A leitura sacralizante}

Certamente, a leitura mais corrente, por ser a mais universal, em termos de cosmovisão religiosa. Trata-se da visão que divide a realidade em dois mundos distintos e opostos: o sagrado e o profano. O clérigo seria o mediador entre esses dois mundos, sendo, por isso mesmo, participante direto do mundo sagrado. A sua condição de consagrado o separa do mundo e o coloca acima das demais pessoas por essa condição. Mircea Eliade demonstrou a estrutura e a dinâmica dessa cosmovisão em suas obras, sobretudo no seu livro clássico sobre a definição e distinção do sagrado e do profano. ${ }^{11}$

É evidente que a teologia do sacerdócio (sacer = sagrado) reforça sobremaneira essa visão, embora ela exista, de fato, em outras religiões e tradições cristãs que não adotam a teologia do sacerdócio para fundamentar e instituir suas lideranças religiosas. A separação entre os sagrados e os profanos termina por estruturar a organização eclesial e as relações entre os membros, reafirmando a ideia de um poder sagrado estabelecido por Deus acima dos fiéis comuns e a postura de receptor passivo dos bens sagrados da parte desses. Essa leitura ignora a realidade mais fundamental do cristianismo que é a encarnação do Verbo de Deus. Em Jesus Cristo, Deus encarnado, fica superada qualquer dicotomia cósmica, social ou politica entre sagrado e profano. Não há legitimidade possível nessas dicotomias no âmbito da fé e da vivência cristã. O filho de Deus feito homem sacraliza o profano, como primogênito de toda a criação, como realização historia da esperança escatológica e como presença misteriosa que funda a Igreja em seu conjunto e se esconde na historia como seu desígnio final. O Espirito Santo, dom do Filho ressuscitado, "enche a orbe da terra" (cf. GS, 11) e continua a engendrar a Igreja dentro da história em cada tempo e lugar.

${ }^{11}$ Cf. ELIADE, M. Sagrado e profano: a essência das religiões. São Paulo: Martins Fontes, 1999, pp. 19-22. 
b) A leitura ontologizante

A distinção entre clero e leigo foi muitas vezes ontologizada, tendo em vista uma soma sincrética de elementos da metafisica grega e da teologia do sacerdócio. Essa leitura não somente justifica e consagra a distinção clero e leigo como as fundamenta em posições ontologicamente distintas e, por conseguinte, fixas e eternas. Fala-se então em ser do padre, ser do bispo e ser do leigo. Separados em suas essências distintas e desiguais, as condições de ordenado e de não-ordenado só podem ser vistas como posicionadas em superioridade de uma sobre a outra, numa hierarquia dos seres portadores de qualidades superiores. O ordenado teria, em termos teológicos, algo a mais que o leigo e não algo diferente do leigo. Essa graduação ontológica se manifestaria no seio da comunidade cristã como perfeição, superioridade, saber, sacralidade, poder etc. O leigo adquiriria, de sua parte, a verdadeira condição daquele a quem falta algo em termos de vida cristã e, portanto, jazendo na condição inferior de vida eclesial menos perfeita. Desse modo, o ordenado torna-se o poder de onde emanam as decisões legitimas que descendem do topo da hierarquia até sua base destituída de autonomia e de qualquer palavra eclesialmente legitima. Essa leitura não somente considera os ministérios como essencialmente hierarquizados em termos de exercício da função, mas também como escalonamento de esferas de funções em si e por si mesmas distintas. Desprovida de qualquer fundamentação bíblica, essa leitura esconde a afirmação de igualdade fundamental dos batizados e, por essa razão, participantes do sacerdócio de Jesus Cristo, assim como fixa em essências imutáveis a vivência do serviço acolhido como graça e como caminho de identificação com Jesus Cristo dentro da história.

\section{c) A leitura tradicionalista}

O específico dessa leitura que, em muitos aspectos, se identifica com a anterior consiste na justificação da dicotomia clero-leigo a partir do fundamento do passado. Trata-se concretamente da fixação em um modelo construído historicamente, porém afirmado como existente desde sempre. Localiza-se, desse modo, exatamente no extremo oposto da leitura anárquica. Para essa leitura não interessa sequer as referências neo-testamentárias que oferecem uma visão de qualquer função como serviço. A referência a uma construção feita no passado, basicamente, na cristandade pós-constatiniana 
torna-se a única possível para se pensar e praticar o serviço na comunidade eclesial. $\mathrm{O}$ tradicionalismo fixa não somente um modelo de organização do passado como único e eterno, como também uma série de procedimentos protocolares de cunho administrativo, de formulações doutrinais e de performances estéticas ligadas a esse modelo. E o que fugir desses parâmetros será visto como heterodoxia e como heresia que desfigura a verdadeira Igreja de Cristo. A legitimidade vinda do passado não permite outras formas de organização do serviço eclesial na direção da pluralidade de serviços e ministérios. O sentido genuíno de tradição como transmissão do carisma cristão em cada tempo e lugar cede lugar à fixação de um único modelo, a partir do qual se lê as mudanças do presente como ameaça à verdade instituída.

\section{d) A leitura do poder}

Uma vez constatada, a dicotomia pode ocorrer em uma leitura que afirma a oposição como clima e estratégia da relação clero e leigo. Tratar-se-ia de uma relação de luta e oposição entre os dois segmentos eclesiais, seja em nome de uma igualdade eclesial fundamental que a todos nivela indistintamente, seja em nome de uma superioridade estabelecida teológica e eclesialmente que se impõe como poder centralizador, do qual decorre, por conseguinte, o "poder" do leigo. Todo serviço e ministério passam a ser vistos como poder exercido em relação aos que não têm poder. $\mathrm{O}$ carreirismo eclesiástico da parte do clero e o carreirismo ministerial da parte do leigo expressam essa visão que se ampara em um escalonamento hierárquico que, de fato, organiza a Igreja em sua estrutura e funcionamento. Ainda que constitua uma concepção e uma prática milenar, essa visão mina qualquer mudança de postura e de estrutura eclesial, bem como institui a regra do apoderamento - em nome de Deus, de Jesus e do Espirito - como caminho inevitável para o agir eclesial, tanto numa visão descendente que domina os não empoderados, quanto numa visão ascendente que disputa poder em nome da igualdade radical dos cristãos. Prevalece nesses casos a adoção da lógica do poder como regra fundamental da pratica dos ministérios e serviços eclesiais.

e) A leitura anárquica

Essa entende que o cristianismo deveria abolir todas as suas organizações históricas de cunho hierárquico, tanto no sentido de uma teologia sacerdotal quanto no sentido da organização escalonada do poder. A igreja deveria, em 
suma, organizar-se como nos tempos primitivos, sem poderes hierárquicos e sem centros decisórios únicos dos quais emanassem normas ou comandos unificados. A vivência cristã negaria por sua radical adesão pessoal e pela liberdade dos fiéis a qualquer modo de organização e de fixação de regras e normas. Nesse sentido, todos seriam iguais, uma vez possuidores da condição comum de batizados e participantes do sacerdócio comum de Cristo, único sacerdote. A teologia do laicato exigiria, desse modo, o fim de qualquer organização eclesial que negasse ou escondesse a condição comum dos fiéis em nome do poder religioso centralizado em algumas funções. Muitos movimentos reformadores aconteceram sobre essa visão desinstitucionalizadora, vindo a compor novas formas de organização eclesial não mais episcopais, mas congregacionais ou sinodais. Em nossos dias é possível observar agremiações pentecostais que se organizam a partir de um acesso carismático ao poder, sem os caminhos previstos pelas instituições tradicionais. No entanto, é preciso observar que, em todos os casos, não se pode verificar uma nivelação total das funções e, menos ainda, a eliminação da distinção entre o especialista religioso (ainda que de tipo carismático) e o fiel comum seguidor da liderança portadora de dons. Ademais, a figura do pastor termina por estruturar, ainda que de forma menos institucionalizada, a distinção hierárquica entre clero e leigos. A visão anárquica ignora o processo histórico de institucionalização do carisma, inerente a todos os movimentos religiosos e que reserva ao carisma puro apenas um momento inaugural. Este momento é sucedido por uma fase institucionalizadora ${ }^{12}$ que, mediante estratégias de transmissão e preservação do carisma, constrói aparatos objetivos, as normas, os papéis e as dinâmicas que garantam o funcionamento da comunidade de fieis. O cristianismo carrega o dom e o desafio da convivência do carisma com a instituição, na medida em que se entende como transmissor do dom do ressuscitado até o fim do mundo e dos tempos.

\section{f) Leitura organicista}

Essa leitura é comum nas teologias dos ministérios. Ela retoma os textos paulinos sobre os serviços e ministérios (cf. 1Cor 12-14), entendidos como diversidade de funções dentro da comunidade, utilizando para tanto a figura do corpo. Não se trata de entrar no mérito dessa teologia normativa para as igrejas cristãs. O fato é que a analogia do corpo muito a gosto das análises

${ }^{12}$ Cf. WEBER, M. Economia y sociedade, p. 857. 
sociais funcionalistas pode esconder as distinções e os conflitos reais que existem na dicotomia clero-leigo, quando não esconder a própria distinção em nome da diversidade exercida na unidade. Nessa leitura, o corpo eclesial seria estruturado por uma diversidade de funções que se complementam no todo da comunidade, de forma que não já não faria diferença ser um ministro ordenado ou não ordenado, ser clero ou leigo. O organismo eclesial precisaria das funções distintas, inclusive hierarquicamente distintas, para funcionar bem. As condições de clero e de leigo são constitutivas do único e mesmo corpo, de forma que deveria evitar qualquer leitura centrada na distinção e na oposição, assim como qualquer leitura que negasse a distinção nos termos do anarquismo. A leitura organicista aplicada a qualquer tipo de organização social e política esconde as diferenças e as divergências em nome do funcionamento geral baseado nas relações de complementariedade orgânica das funções. Ficam, desse modo, justificadas e legitimadas as reais dicotomias clero-leigo em nome de uma comunhão maior, na verdade, em nome de uma estrutura geral e fixa que dispensa não somente pensar em reformas estruturais, como também em expor as dicotomias, as centralizações e os desmandos de poder.

Essas intepretações podem misturar-se nas vivências eclesiais, ora complementando-se, ora opondo-se uma a outra. São tendências que focam a interpretação naquilo que não constitui a Igreja como tal. Todas ignoram um dado fundamental: a construção histórica do cristianismo realizada a partir da fé no Ressuscitado que envia os discípulos a evangelizar até o fim dos tempos na força do Espírito. A ilusão de uma organização eclesial pronta, fixa e eterna deixa de lado a fé mais básica do cristianismo: o Espirito do Ressuscitado que constrói a Igreja distribuindo a cada qual seu dom no tempo de hoje. É nessa fé e nessa pratica que as primeiras comunidades organizaram seus serviços e ministérios e só pode ser sobre ela que nos séculos seguintes a Igreja foi se organizando com novos modelos.

\section{A superação da dicotomia}

Dentre as "reformas inadiáveis" a serem feitas na Igreja (cf. EG, 27) estão aquelas que se referem à organização dos serviços e, por conseguinte, às relações entre o clero e o leigo. O peso histórico, institucional e até mesmo teológico da separação entre clero e leigo não pode dispensar leituras críticas que contribuam com a superação dessa tradição e práxis antievangélicas. Esse é o papel específico da teologia, enquanto reflexão crítica da realidade a 
partir da fé. O discernimento da realidade presente é a postura e o método não somente da teologia, mas de todo o Povo de Deus, ensina o Vaticano II (cf. GS, 11; PO, 9). Nesse sentido, há que distinguir clericalismo de clero, poder de serviço, assim como especificidade de funções de superioridade de funções, ou, ainda, ministério instituído de ministério burocratizado. Não podemos cair na mistificação das nomenclaturas (todos são leigos ou todos são cleros) ou das eclesiologias (todos somos povo de Deus) como conceitos genéricos e mágicos que por si mesmos trariam mudanças na práxis ministerial da Igreja. De outra parte, a afirmação de que "sempre foi assim" não resiste há muito às criticas históricas que revelam o processo de construção da organização da Igreja no decorrer do tempo.

O cristianismo se define pelo seguimento a Jesus Cristo que veio para servir e não para ser servido (cf. Mt 10,35-45). Qualquer postura que desviar ou ocultar essa verdade fundamental será anticristã, ainda que revestida de autoridade instituída ou de sacralidade socialmente reconhecida. Todos conhecemos clérigos e leigos que vivem o serviço como máxima de vida. Também experimentamos nos anos pós-concilio mudanças praticas no âmbito pastoral de muitas igrejas particulares que se organizaram pastoral e ministerialmente em formas participativas regidas pela complementaridade de serviços e funções, onde ser clero e leigo tornou-se, de fato, apenas um serviço distinto na mesma comunidade de fé. As assembleias de pastoral realizadas nos âmbitos paroquial e diocesano constituíram experiências singulares de participação efetiva de todo o povo de Deus no discernimento dos rumos e nas definições de metas e práticas das igrejas. Esses testemunhos foram muito importantes, porém se inscrevem na história dos bispos e padres renovadores, carismáticos tragados pela estrutura institucional com suas tradições rígidas que se impõem como legitimas e necessárias ao bem geral da Igreja. Foi esse o processo que vivenciamos nos últimos tempos na Igreja e que persiste, mesmo depois das exortações de Francisco às mudanças da Igreja.

De fato, há uma práxis eclesial - uma representação e uma prática coletiva, instituída e teologicamente legitimada - que pode dispensar por sua institucionalidade-legalidade provocações teológicas à mudança. Em outros termos, não basta testemunho individual de bispos, padres, religiosos e leigos; é necessário ir além, pensar em mudanças de mentalidade e mesmo de estruturas para que a dicotomia seja eliminada em sua raiz. A Igreja em saída se faz no caminho como servidora do Reino de Deus. O que não contribui com essa missão será sobra inútil, excesso de peso que poderá fazer a Igreja naufragar 
e que deverá ser jogado fora. É verdade que todos temos imensa dificuldade em desfazer-nos de nossas bagagens, mesmo aquelas que nos deixam exaustos e dificultam nossa caminhada com maior agilidade. Preferimos a segurança do passado ao desafio da construção presente. Em tempos de mudança, como vemos hoje, esse apego fica ainda mais forte por nos dar segurança e, supostamente, um rumo certo em meio ao pluralismo de valores e ao relativismo. É verdade que, de sua parte, a Igreja tem mais facilidade em preservar do que de desfazer-se de seus acúmulos históricos que vão sendo formalizados e sacralizados. Contudo, como bem orienta o Papa Francisco, o desafio da renovação é hoje urgente. A sociedade muda com velocidade alucinante devido aos domínios incessantes das tecnologias; avança no conhecimento e na divulgação dos mesmos em esfera planetária. As instituições tradicionais vão perdendo sua força cultural e moral como fornecedoras de regras de vida e de metas sociais. A separação dicotômica entre clero-leigo constitui um modelo social e político cada vez mais sem sentido para nossos dias de democratização das informações, de emergência das minorias e de apelos por modos participativos de convivência. A insistência no poder clerical é a "vanglória de quantos se contentam com algum poder e preferem ser generais de exércitos derrotados antes que simples soldados dum exército que continua a lutar" (EG 96) É verdade que não devemos reproduzir tudo o que a sociedade adota como regime de vida ou como regra. Mas também é verdade que devemos discernir a realidade para que possamos anunciar o Evangelho de modo mais claro e convincente. Certamente, está na hora de tirarmos as consequências concretas da eclesiologia proposta pelo Concilio Vaticano II, em termos de renovação da estrutura da Igreja: organizada em formas mais participativas, transparentes, descentralizadas e inclusivas. Para tanto, será necessário conversão de mentalidades e renovação institucional.

O Vaticano renovou a mentalidade eclesial, mas a estrutura da Igreja permaneceu praticamente inalterada. Hoje vivemos o que parece o inverso. $\mathrm{O}$ Papa propõe renovação da estrutura e a mentalidade da maioria dos clérigos permanece conservadora, indiferente ou resistente às mudanças. O clericalismo pode ser um bem-estar para aqueles que detêm a função e se assentam na segurança do poder para exercer o ministério, dispensando o questionamento e o diálogo, ações nem sempre confortáveis. No entanto, trata-se de um isolamento na bela torre de marfim, donde se enxerga por cima e se decide de cima, mas sem a eficácia do testemunho e a transformação feita pelo serviço. 
A dicotomia clero-leigo há que ser superada com as próprias "ferramentas" da tradição cristã, mesmo que no mundo de hoje esteja fadada ao fracasso real como uma espécie de folclore eclesial que alguns gostam de exibir para alguns que gostam de ver. Temos que começar eliminando ou revendo as visões que a afirmam e legitimam como verdadeira e necessária para a vida da Igreja. A primeira estratégia é, por certo, a dessacralização das estruturas institucionais. As estruturas da Igreja são construídas para preservar e transmitir o carisma salvífico de Jesus Cristo a cada geração. Esse é absoluto, aquela é relativa. $\mathrm{O}$ perigo consiste em usar as fontes do carisma para preservar a estrutura de modo intacto, como se tudo procedesse diretamente do Evangelho. Francisco nos ensina que é do "coração do Evangelho" que buscamos a fundamentação de tudo o é a Igreja e do que ela faz. A dessacralização das estruturas significa também dessacralização das funções individualizadas do ministério ordenado, de modo a recolocá-lo dentro da Igreja, de onde ele provém e para a qual ele é exercido. Dessacralizar não significa diminuir a dignidade e nem negar o fundamento da função no mistério de Cristo, mas, ao contrário, localizar a fonte do ministério no seu lugar preciso: no Cristo vivo que gera a Igreja na história pela força de seu Espirito. Nesse mistério não há mais dualização entre sagrados e profanos, todos se inserem numa realidade misteriosa que se funda no próprio Cristo vivo na história. Nessa realidade pneumático-eclesial se inserem todos os serviços, dela se alimentam e para ela atuam. O que se afirma de sagrado para os ministérios só tem sentido nessa fonte primeira e comum, do contrário haverá concentração pessoal de uma sacralidade sem fundamento teológico, mais próxima da mentalidade pagã do que do cristianismo. Os ministérios existem na, para e com a Igreja e não como um poder em si mesmo. O Papa João Paulo II fala de uma circularidade entre a realidade fundante da Igreja onde todos os fiéis se igualam pelo mistério da inserção na Igreja pelo batismo e o ministério episcopal:

A reciprocidade, que existe entre sacerdócio comum dos fiéis e sacerdócio ministerial e se encontra no próprio ministério episcopal, manifesta-se numa espécie de «circularidade» entre as duas formas de sacerdócio: circularidade entre o testemunho de fé de todos os fiéis e o testemunho de fé autêntica do Bispo nos seus atos magisteriais; circularidade entre a vida santa dos fiéis e os meios de santificação que o Bispo lhes oferece; por último, circularidade entre a responsabilidade pessoal do Bispo pelo bem da Igreja a ele confiada e a corresponsabilidade de todos os fiéis relativamente ao bem da mesma (Pastores Gregis, 10). 
O clericalismo nega qualquer circularidade e se isola em uma sacralidade intransitiva superior, definida por si mesma como essência própria, acima do conjunto do povo de Deus e como origem da legitimidade de toda ação pastoral na comunidade eclesial. O mistério fundante da Igreja exige que sejam superadas as sacralizações do poder enquanto tal, desvinculadas da vida eclesial.

A superação da dicotomia acontecerá também na medida em desconcentrar as funções, muitas vezes concentradas nas mãos do clero. Não se trata de uma luta pelo poder sagrado ou por uma espécie de exercício democrático do poder religioso. A Igreja não é, de fato, uma democracia, por não se definir como poder, mas uma fraternidade, ou seja, uma comunidade de membros iguais inseridos no mesmo mistério de salvação que se define pelo serviço e pelo amor. A desconcentração dos serviços hoje concentrados no clero já foi vivenciada em muitas Igrejas da América Latina e poderá ainda progredir para modos mais ousados que avancem na direção de uma maior participação dos fieis nos serviços eclesiais; participação que contribua com a superação do dualismo clero-leigo, na medida em que a corresponsabilidade vai efetivando a missão comum dos batizados e desmentindo, na prática, a relação assimétrica entre poder sagrado individualizado e serviços eclesiais.

Fora do serviço não há ministério legítimo na comunidade cristã. Qualquer teologia do ministério - do sacerdócio, da ordem, do poder sagrado, da diversidade de ministérios etc - só tem sentido como serviço. E o que se apresenta essencialmente como poder não poderá servir, embora possa exercer uma função religiosa eficiente dentro de um grupo. O poder se alimenta do domínio de uns sobre os outros, jamais na relação de fraternidade. O clericalismo é, na verdade, exercido como administração e magia. Administração da estrutura eclesial, incluindo evidentemente seu aspecto econômico e de sua agenda de serviços religiosos e serviços sagrados oferecidos aos indivíduos que o buscam com motivações variadas. A concentração dos serviços sagrados por um "ser sagrado" reproduz a mentalidade mágica das religiões, quando um indivíduo detentor de poderes sagrados oferece seus serviços eficazes a quem deles necessita. Nesse sentido, a pratica clericalista se completa com o uso passivo dos leigos dos serviços sagrados. Ao clero cabe o protagonismo da função sagrada, ao leigo a sua utilização; àquele o conhecimento e a decisão, a esses a aprendizagem e a submissão.

Na comunidade cristã, a renúncia ao poder foi uma regra que construiu o ethos comum dos seguidores de Jesus Cristo como testemunham os textos do Novo Testamento. ${ }^{13}$ Cada membro deve servir como Jesus serviu. Na ordem

${ }^{13}$ Cf. THEISSEN, G. A religião dos primeiros cristãos. São Paulo: paulinas, 2009, pp. 97-119. 
dos seguidores, ser o primeiro é, na verdade, ser o último (cf. Mc 10,43-44; Mt 23,11) e cada qual deve exercer a função na comunidade sem competição e vanglória (cf. Fl 2,3).

\section{Conclusão}

Por certo não encontraremos o clericalismo em estado puro, como acima descrito. Mas, pode ser visto a olho nu em doses fortes e como tendência crescente na Igreja atual. Seja como for, trata-se de um vício de poder e de um desvio eclesial que deve ser eliminado em nome da fé. ${ }^{14}$ A postura e estratégia do clericalismo escondem, na verdade, fragilidades pessoais de seus portadores que, em nome do poder sagrado, dispensa o confronto e o diálogo com o mundo atual e a postura do serviço como regra de vida. Trata-se de uma postura estabelecida que garante o exercício do ministério como direito individual, de certo modo assegurado por uma estrutura jurídica, o que se dá com ou sem a inserção real do ordenado na comunidade de fé e a participação efetiva da mesma na organização dos serviços. A ordenação é vista, nesse caso, como poder recebido anterior e acima da comunidade eclesial à qual se relaciona na pratica pastoral concreta.

Uma Igreja feita de sujeitos eclesiais maduros, conscientes, autônomos e responsáveis ${ }^{15}$ ainda é um desafio para a Igreja, não obstante os fundamentos teológicos colocados pelo Vaticano II. A bela teoria do laicato ainda deve ser colocada em prática, dizia o Papa João Paulo II. ${ }^{16}$ A tomada de consciência da subjetividade eclesial, assinala Francisco, é impedida pelo clericalismo que mantém os leigos "às margens das decisões" (EG 102). Contudo, cada discípulo é um sujeito ativo da evangelização, independente da qualificação que possua, alerta ainda o Papa (cf. EG 120).

A liderança eclesial entendida como serviço e não como poder (cf. EG 104) supera as individualizações dos ministérios (cf. EG 81), a rotina que traga no pragmatismo da função administrativa a vivacidade do Evangelho e a egolatria que conduz ao pecado de querer ser Deus, que acompanha o ser humano desde às origens (cf. Gn 3,5). A renovação da Igreja, convocada por Francisco, exigirá de imediato a superação das mentalidades e práticas clericalistas, a desconcentração de funções e, por certo, a recolocação de certas

\footnotetext{
${ }^{14}$ Cf. DEBARGÉ, P. Ética do poder. São Paulo: Paulinas, 2002, pp. 85-115.

${ }^{15}$ Cf. CNBB, Documento 107, n 10, 47-51.

${ }^{16}$ Cf. Christifidelis Laici, n. 2.
} 
regras que regem canonicamente a função. No entanto, antes disso, a fé nos indica o rumo fundamental do serviço à Igreja e ao Reino. A distinção clero e leigo continuará existindo na comunidade católica com seus elementos oriundos de uma mentalidade politica pré-moderna e com sua teologia do poder estranha à concepção cristã. Porém, ela será sempre provocada pelas fontes bíblicas cristãs que pedem novas formas de institucionalizar as funções como serviço à comunidade e ao mundo. O "coração do evangelho" tem força renovadora permanente e será sempre uma norma primeira que exige a postura de serviço por parte de todos os ministros da Igreja; dessa força advém a renovação permanente da Igreja, ainda que em doses pequenas e de maneira lenta. A superação de estruturas paroquiais anônimas e massificantes em benefício de pequenas comunidades reconstrói uma configuração de base na qual os ministérios são exercitados na relação interpessoal direta como serviço e como encontro. A vida comum constitui um caminho natural de superação da sacralização individualizada da função ministerial por parte dos ministros ordenado e não-ordenado e de recriação das relações familiares onde, de fato, a figura paterna do líder - ainda que a expressão Padre esteja tão rotinizada - readquire seu significado mais antigo e, ao mesmo tempo, mais atual como aquele que conduz no afeto e na dedicação sua família. E Igreja de padres e de madres será mais fraterna e menos monárquica e, por conseguinte, testemunha viva de uma organização dinamizada em nome do amor.

A distinção de funções em razão do serviço comum na comunidade não configura distinção dicotômica e muito menos exercício de poder de alguns sobre outros. Essa distinção se inscreve nas formas de mundanismo espiritual descritas pelo Papa Francisco e clama por mudanças urgentes em razão de nossa fé em Jesus Cristo:

Quem caiu neste mundanismo olha de cima e de longe, rejeita a profecia dos irmãos, desqualifica quem o questiona, faz ressaltar constantemente os erros alheios e vive obcecado pela aparência. Circunscreveu os pontos de referência do coração ao horizonte fechado da sua imanência e dos seus interesses e, consequentemente, não aprende com os seus pecados nem está verdadeiramente aberto ao perdão. É uma tremenda corrupção, com aparências de bem. Devemos evitá-lo, pondo a Igreja em movimento de saída de si mesma, de missão centrada em Jesus Cristo, de entrega aos pobres. Deus nos livre de uma Igreja mundana sob vestes espirituais ou pastorais! Este mundanismo asfixiante cura-se saboreando o ar puro do 
Espírito Santo, que nos liberta de estarmos centrados em nós mesmos, escondidos numa aparência religiosa vazia de Deus. Não deixemos que nos roubem o Evangelho! (EG 97).

\section{Referências bibliográficas}

COMPÊNDIO DO VATICANO II. Petrópolis: Vozes, 1986.

V CONFERÊNCIA GERAL DO EPISCOPADO LATINO-AMERICANO CARIBENHO. Documento de Aparecida. Brasília: Edições CNBB-São Paulo: Paulinas/Paulus, 2007.

CNBB. Estudos da CNBB 107. Brasília: Edições CNBB, 2014.

DEBERGÉ, Pierre. Ética do poder: abordagem bíblico-teológica. São Paulo: Paulinas, 2002.

FRANCISCO. Exortação Evangelii gaudium. São Paulo: Paulinas, 2013.

JOÃO PAULO II. Exortação Christifidelis laici. São Paulo: Paulinas, 1989.

JOÃO PAULO II. Exortação Pastores Gregis. São Paulo: Paulinas, 2003.

PARRA, Alberto. Os ministérios na Igreja dos pobres. Petrópolis: Vozes, 1999.

PASSOS, J. Décio. Concilio Vaticano II: reflexões sobre um carisma em curso. São Paulo: Paulus, 2014.

PASSOS, J. Décio (org.). Sujeitos no mundo e na Igreja: reflexões sobre o laicato a partir do concilio Vaticano II. São Paulo: Paulus, 2014.

RUSCONI, Carlo. Dicionário de grego do Novo Testamento. São Paulo: Paulus, 2003.

TABORDA, Francisco. A Igreja e seus ministérios: uma teologia do ministério ordenado. São Paulo: Paulus, 2012.

THEISSEN, Gerd. A religião dos primeiros cristãos; uma teoria do cristianismo primitivo. São Paulo: Paulinas, 2009.

WEBER, Max. Economía y sociedad. Mexico: Fondo de Cultura Económica, 1997. 
João Décio Passos

Doutor em Ciências Sociais pela PUC-SP

Livre docente em teologia pela PUC-SP

Professor Associado do Departamento de Ciências da Religião da PUC-SP

Professor do Instituto São Paulo de Estudos superiores

São Paulo / SP - Brasil

E-mail: jdpassos@pucsp.br

Recebido em: 01/12/14

Aprovado em: 25/02/15 